\title{
PENINGKATAN MANAJEMEN PRODUKSI PAKAN PELET KELINCI DI DESA AMPERA RAYA
}

\author{
Duta Setiawan ${ }^{1}$, Yeti Rohayeti ${ }^{2}$ \\ ${ }^{1}$ Universitas Tanjungpura. Email: duta.setiawan@faperta.untan.ac.id \\ 2Universitas Tanjungpura. Email: yeti.rohayeti@faperta.untan.ac.id
}

\begin{abstract}
The purpose of activities community service in Ampera Raya village, Sungai Raya Sub district to increased capacity livestock farming rabbits management intensive and livestock farmer productivity through technology rabbit pellet feed. This activity collaborates with 2 livestock farmer groups namely the Master farmer group and the Armada livestock group. The problem of Armada livestock group partners is that cultivation is still extensive and the partners of the Master Farmer Group are expensive prices commercial rabbit feed. Approach methods include Counseling about the importance of rabbit cultivation in livestock raising, especially maintenance of tillers to increase production because mother rabbits have the nature of nurturing weak children, causing many deaths in rabbits and the importance of independently procuring seeds and feed, so that eventually it can increase income of livestock farmer groups. Partner training and mentoring about battery housing technology and manufacture of rabbit feed based on sago waste. The results of community service is the use of a pellet machine can produce cheaper pellets of Rp. $3000 / \mathrm{kg}$.
\end{abstract}

Keywords: rabbit, production management, feed

\begin{abstract}
ABSTRAK
Tujuan kegiatan pengabdian kepada masyarakat desa Ampera Raya kecamatan Sungai Raya melalui kegiatan ternak kelinci adalah peningkatan kemampuan manajemen budidaya ternak kelinci secara intensif dan produktivitas petani ternak kelinci melalui teknologi pembuatan pellet pakan kelinci. Kegiatan PKM ini bekerja sama dengan 2 kelompok tani ternak yaitu kelompok tani Master dan kelompok ternak Armada. Permasalahan mitra kelompok ternak Armada adalah budidaya masih ekstensif dan mitra Kelompok tani Master adalah harga pakan kelinci komersial yang mahal. Metode pendekatan meliputi: Penyuluhan tentang pentingnya budidaya kelinci dalam pemeliharaan ternak khususnya pemeliharaan anakan untuk meningkatkan produksi karena induk kelinci memiliki sifat mengasuh anakyang lemah, menyebabkan banyak kematian pada anak kelinci dan pentingnya pengadaan bibit dan pakan secara mandiri, sehingga akhirnya akan dapat meningkatkan pendapatan masyarakat kelompok tani ternak. Pelatihan dan Pendampingan mitra tentang teknologi perkandangan baterai dan pembuatan pakan kelinci berbasis limbah sagu. Hasil pengabdian masyarakat ini adalah penggunaan mesin pellet dapat menghasilkan pellet yang lebih murah yaitu Rp 3000/kg.
\end{abstract}

Kata Kunci: kelinci, manajemen produksi, Pakan

\section{PENDAHULUAN}

Ampera Raya merupakan wilayah Kecamatan Sungai Raya Kabupaten Kubu Raya. Lokasi desa Ampera Raya berjarak $8 \mathrm{~km}$ sebelah utara kota Pontianak (Universitas Tanjungpura). Luas wilayah Desa Ampera Raya 0,78 km2 denga batas wilayah: Utara 
berbatasan dengan Sungai Landak (Desa Mega Timur), sebelah Timur berbatasan dengan Sungai Ambawang (Desa Sungai Ambawang Kuala), sebelah Selatan berbatasan dengan Parit Ampera Desa Durian Kecamatan Sungai Ambawang dan Kelurahan Saigon Kecamatan Pontianak Timur, sebelah Barat berbatasan dengan Kelurahan Tanjung Hulu Kecamatan Pontianak Timur. Desa Ampera Raya merupakan desa dengan tingkat kepadatan penduduk tertinggi di wilayah Kecamatan Sungai Ambawang, yaitu 818 jiwa /km2 dengan jumlah penduduk 638 orang (Kecamatan Sungai Ambawang Dalam Angka, 2015).

Desa Ampera Raya merupakan salah satu desa yang berada di pinggiran Sungai Landak terbiasa berkebun dan beternak. Terdapat 2 (dua) kelompok tani budidaya kelinci yaitu "Kelompok Ternak Armada" dan "Kelompok Tani Master" dengan jumlah total 82 ternak dengan sebagian besar dipelihara tanpa memiliki kandang hidup di dalam tanah. Namun karena budidaya kelinci dalam ternak hanya sebagai usaha sampingan, maka pada umumnya dalam skala usaha kecil. Umumnya seorang petani memiliki kurang lebih 4-5 ternak kelinci.

Kelinci mempunyai sistematika penamaan sebagai berikut: Ordo: Lagomorpha, Famili: Leporidae, Sub famili: Leporine, Genus: Lepus, Orictolagus, Spesies: Lepus spp., Orictolagus spp., (Suci dan Khotijah, 2017). Sarwono (2001) menyatakan bahwa kelinci lokal mempunyai ciri-ciri : bentuk dan bobotnya kecil sekitar 1,5 kg, bulu bervariasi putih, hitam, belang, maupun abu-abu. Kelinci mempunyai potensi sebagai penghasil daging yang baik karena kelinci sangat cepat berkembangbiak, seekor induk misalnya dapat beranak 4 kali dalam setahun dengan sekali beranak dapat menghasilkan anak sebanyak 4-8 ekor anak kelinci (Hendra, 2009). Selain karena tingkat reproduksi yang tinggi, kelinci juga dapat menggunakan protein nabati secara efisien, makanan relatif tidak bersaing dengan manusia, dapat dipelihara dalam skala kecil dengan menggunakan lahan yang tidak luas dan kandungan nutrisi pada dagingnya cukup tinggi (Cheeke, 1987). Menurut Chan et al. (1995) daging kelinci merupakan daging yang sehat karena memiliki kandungan protein 21,9\% lebih tinggi daripada daging ayam 20,9\% dan domba 20,2\% sedangkan lemak kelinci hanya 5,5\% lebih rendah dibandingkan sapi 8,3\%. Selain itu, daging kelinci memiliki kandungan kolesterol $0,053 \%$ dan natrium $0,067 \%$ lebih rendah dibandingkan daging ayam yang memiliki kolesterol 0,105\% dan natrium 0,09\%.

Kendala yang dihadapi oleh petani ternak kelinci saat ini adalah, ketika mereka selesai panen besar keagamaaan maupun pesanan dari warung-warung pecel lamongan maka mereka juga akan kehabisan bibit. Untuk mendapatkan bibit kelinci, petani selama ini masih mengandalkan bibit sendiri atau membeli dari daerah Singkawang dan didatangkan dari Jawa. Setiap bibit kelinci yang lepas sapih dengan harga Rp 35.000/ekor (Tamba dkk., 2006). Kalau bibit dari hasil bibit sendiri kebanyakan kawan saudara atau in breeding, sedangkan pembelian bibit dari Singkawang jauh dan banyak kematian di jalan karena jarak yang jauh dan strees. Hal itu disebabkan karena keterbatasan pengetahuan dan teknologi yang dimiliki petani tentang teknologi pembibitan. Padahal dengan pembibitan sendiri, maka stok bibit kelinci akan lebih cepat tersedia dan ekonomis. 
Pada umumnya petani di Desa Ampera Raya budidaya kelinci dalam ternak hanya sebagai usaha sampingan dalam skala usaha kecil. Kendala yang dihadapi adalah manajemen budidaya, pengadaan bibit kelinci yang mahal, menyebabkan sirkulasi produksi kelinci menjadi tidak lancar. Hal ini karena terbatasnya pengetahuan yang dimiliki petani tentang manajemen budidaya ternak kelinci. Kendala lain adalah mahalnya harga pakan, sedangkan tingkat ketergantungan terhadap pakan pabrikan (komersiil) sangat tinggi. Sehingga berpengaruh terhadap pemberian pakan tidak sesuai standar kebutuhan, yang mengakibatkan pertumbuhan kelinci kurang maksimal. Hal ini karena terbatasnya pengetahuan petani tentang teknologi pembuatan pakan kelinci dengan menggunakan bahan baku limbah lokal, seperti: lumpur sawit, ampas kelapa, bungkil kopra hasil, ampas tahu, sisa-sisa ikan rucah, keong mas, dan kulit udang (Febriana, 2005). Dengan pengadaan kelinci secara mandiri maka ketersediaan pakan akan mudah didapat dengan harga yang relatif murah.

Berdasarkan uraian diatas, prioritas permasalahan Mitra I kelompok tani Ternak Ampera adalah: a) Mahalnya pengadaan bibit kelinci dalam jumlah banyak dan waktu yang cepat sebagai replacement stock dari kelinci yang sudah dijual untuk di potong, disebabkan karena kurangnya pengetahuan tentang teknologi budidaya kelinci, b) Mahalnya harga pakan kelinci menyebabkan biaya produksi tidak sebanding dengan hasil yang diperoleh, sedangkan disekitar desa tersebut tersedia banyak limbah lokal yang berpotensi sebagai bahan baku pakan kelinci . Disisi lain prioritas permasalahan Mitra II kelompok tani Master adalah: a) Skala usaha kecil, rata-rata kepemilikan kelinci sebanyak 4-5 ternak karena terbatasnya modal, b) Mahalnya harga pakan kelinci komersiil, menyebabkan pertumbuhan kelinci kurang maksimal, sehingga biaya produksi tidak sebanding dengan penghasilan.

\section{METODE PELAKSANAAN}

Metode yang dilakukan oleh Tim PKM dalam melaksanakan solusi dari permasalahan Mitra kelompok peternak kelinci untuk memperbaiki sistem budidaya, meningkatkan produksi dan membuat pakan mandiri sehingga mitra dapat memproduksi pakan konsentrat kelinci berbasis bahan limbah sagu untuk mencukupi kebutuhan anggota dengan harga murah, dan sesuai dengan kebutuhan gizi ternak kelinci di daerah Ampera Raya dengan mengunakan berbagai tahap kegiatan yaitu: Melakukan sosialisasi dengan cara mengumpulkan khalayak sasaran yaitu kelompok ternak Armada dan kelompok tani Master pada suatu tempat pertemuan yang dihadiri oleh pemerintah desa untuk diberikan penjelasan tentang rencana kegiatan PKM di Mitra yang meliputi aspek a) Bagaimana membuat kandang baterai untuk memudahkan budidaya dan recording kelinci, b) Bagaimana menyusun pakan tambahan kelinci dengan memanfaatkan bahan baku pakan limbah lokal yang murah dan memenuhi kebutuhan gizi ternak kelinci. c) Tata cara penggunaan dan perawatan peralatan d) Praktik produksi pembuatan pakan pelet kelinci. Tujuan metode ini adalah untuk meningkatkan pengetahuan budidaya para peternak kelinci di Desa Ampera Raya. Kegiatan PKM ini juga diikuti dengan diskusi dua arah terkait permasalahan maupun materi kegiatan yang bertujuan untuk tukar pengalaman antara tim PKM dengan 
peternak penerima manfaat kegiatan ini. Kelompok Ternak Armada dan Master diberi fotocopi materi kegiatan.

Bantuan kegiatan PKM seperti kandang baterai, wajan, nampan, kompor, oven, timbangan, mesin pelet kepada peternak kelinci dan bahan pakan penyusun pellet. Pelaksanaan kegiatan ini akan melibatkan beberapa anggota kelompok peternak kelinci khususnya penduduk Desa Ampera Raya dengan tujuan memberi contoh riil dilanjutkan praktek penggunaan alat. Sesuai dengan komitmen pada saat koordinasi awal penyusunan usulan proposal PKM, peternak kelinci melakukan perbaikan sistem budiaya dari ekstensif menjadi intensif. Praktek secara berkelompok tentang penyusunan pakan pellet dengan memanfaatkan potensi lokal limbah sagu dan tepung daun tanaman pakis yang banyak terdapat di desa Ampera Raya dan sekitarnya, sehingga bisa dihasilkan produk pakan konsentrat yang murah dan bergizi. Produksi pakan pellet di peternak, pengemasan dan pemasaran untuk memenuhi kebutuhan konsentrat anggota kelompok peternak kelinci, dan pasar umum.

\section{HASIL DAN PEMBAHASAN}

Tim PKM ternak kelinci dalam melaksanakan solusi dari permasalahan Mitra kelompok ternak Armada dan Master, untuk meningkatkan produksi dan memperbaiki manajemen sehingga Mitra dapat memproduksi pakan konsentrat kelinci berbasis bahan lokal untuk mencukupi kebutuhan anggota dengan harga murah dibandingkan dengan konsentrat dijual komersial dengan perbedaan harga Rp 3000/ kg tertera pada Gambar 1. Penjualan pakan pelet kelinci dijual ke anggota akan semakin mendorong usaha berkembang, biaya produksi dapat ditekan, dan jaminan keberlanjutan produksi ternak kelinci.

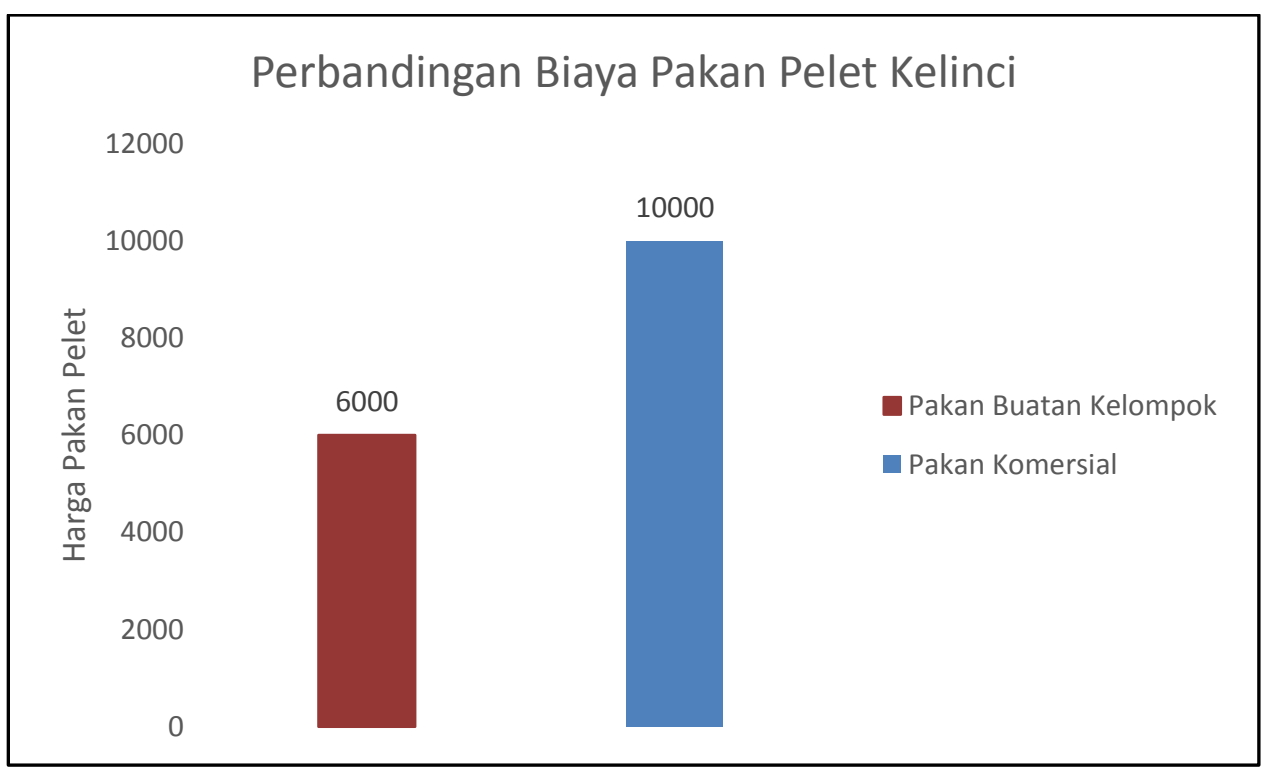

Gambar 1. Biaya Pakan Pelet Kelinci di Desa Ampera Raya

Ketua kelompok ternak kelinci Armada dan Master dan Tim PKM mengumpulkan khalayak sasaran pada tempat pertemuan di dirumah ketua kelompok ternak kelinci untuk diberikan penjelasan tentang rencana kegiatan PKM di mitra 
yang meliputi aspek a) Bagaimana membuat kandang baterai untuk memudahkan budidaya dan recording kelinci, b) Bagaimana menyusun pakan tambahan kelinci dengan memanfaatkan bahan baku pakan limbah lokal yang murah dan memenuhi kebutuhan gizi ternak kelinci. c) Tata cara penggunaan dan perawatan peralatan d) Praktek produksi pembuatan pakan pelet kelinci. Untuk meningkatkan pengetahuan kelompok ternak kelinci Armada dan Master mengenai materi kegiatan. Kegiatan ini diikuti dengan diskusi tentang materi kegiatan yang bertujuan untuk tukar pengalaman antara tim penyuluh dengan khalayak sasaran. Khalayak sasaran diberi brosur yang berisi tentang materi kegiatan.

Alat yang diperlukan untuk membuat pakan pellet ternak kelinci dengan menggunakan peralatan sederhana meliputi wajan, nampan, kompor, timbangan, Oven, Mesin pembuat pellet. Proses pembuatan pelet pakan kelinci seperti pada Gambar 2.

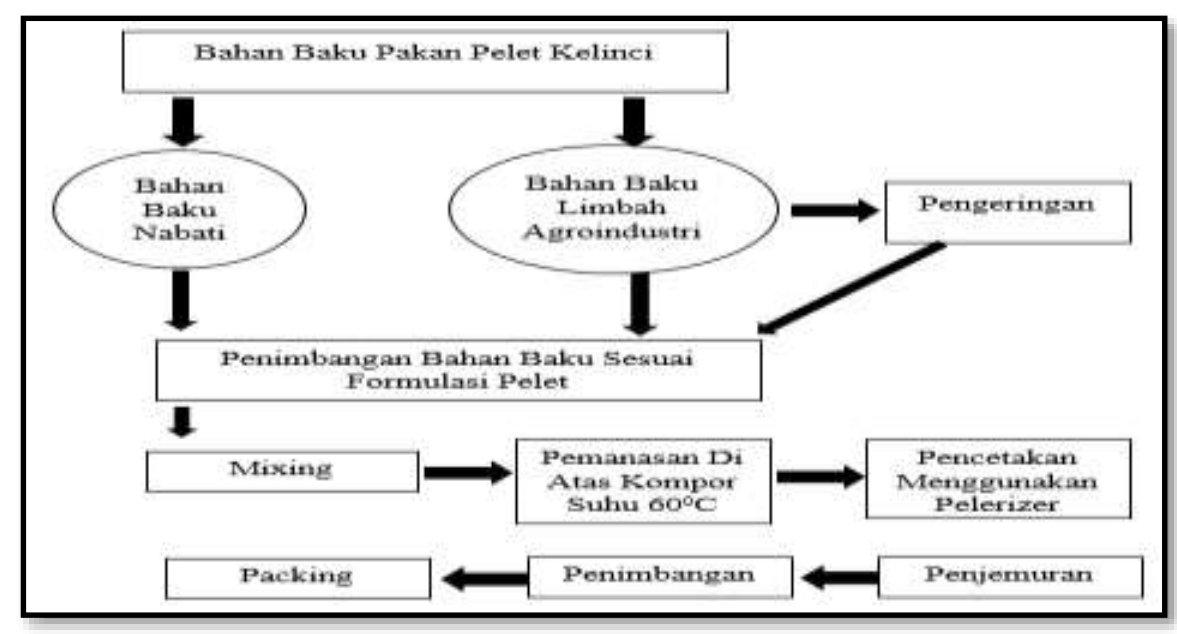

Gambar 2. Diagram Alir Pelet Kelinci

Cara pembuatan dan pemberian pakan pellet pada kelinci: Bahan yang digunakan meliputi tepung sagu afkir, serat ampas sagu, ampas tahu, bekatul, bungkil kelapa, lumpur sawit, tepung jagung, premix, garam, tepung ikan dan mie afkir. Semua bahan penyusun pellet kelinci ditimbang dengan proporsi sesuai kebutuhan pada kelinci. Semua bahan konsentrat kemudian dicampur dan diaduk sampai semua bahan rata. Kemudian tambahkan premix dan bungkil kelapa aduk rata. Tambahkan ampas tahu, Aduk kembali hingga homogen. Semua pakan yang telah diaduk rata dimasukkan ke dalam mesin pembuatan pellet. Pakan pellet berbasis bahan limbah sagu siap untuk diberikan kepada ternak kelinci. Foto-foto kegiatan pembuatan pellet kelinci di Desa Ampera Raya seperti pada Gambar 3. Guna mengoptimalkan penyelesaian masalah pada Mitra kelompok peternak kelinci Armada dan Master, tim PKM memberikan bantuan sarana pendukung mesin pelet kepada Mitra Kelompok serta beberapa bahan pakan penyusun konsentrat. 


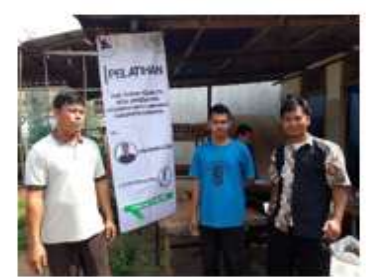

A. Kegiatan Pelatihan

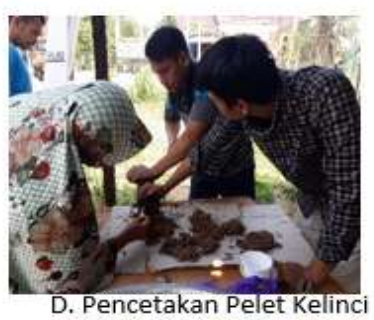

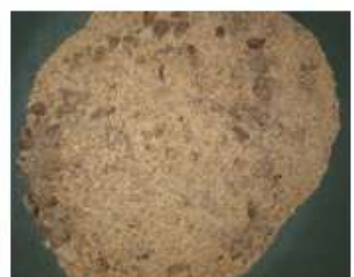

B. Campuran Bahan Baku

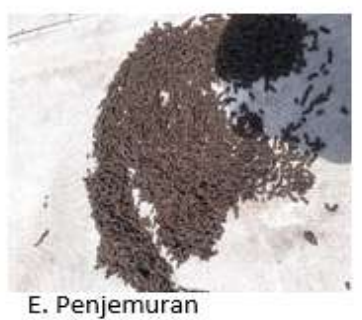

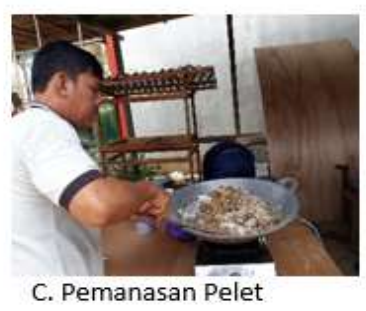

C. Pemanasan Pelet

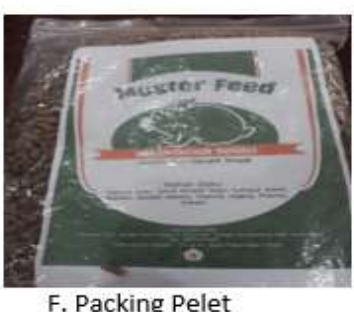

Gambar 3. Kegiatan Pembuatan Pelet Kelinci di Desa Ampera Raya

Pelaksanaan kegiatan ini akan melibatkan beberapa anggota asosiasi peternak kelinci khususnya penduduk Desa Ampera Raya dengan tujuan memberi contoh riil dilanjutkan praktik penggunaan alat. Hasil pengabdian masyarakat, penggunaan mesin pellet dapat menghasilkan pellet yang lebih murah sebesar Rp 3000/kg dibandingkan dengan pelet komersial.

\section{SIMPULAN}

Pelaksanaan kegiatan PKM ternak kelinci di desa Ampera Raya kecamatan Sungai Ambawang Kabupaten Kubu Raya berjalan sesuai petunjuk pelaksanaan kegiatan dengan capaian sebagai berikut: Pertemuan sosialisasi, rapat, pelatihan dan pendampingan dengan mitra kelompok Armada dan kelompok Master. Hasil pengabdian masyarakat, penggunaan mesin pellet dapat dapat menghasilkan pellet yang lebih murah sebesar Rp 3000/kg dibandingkan dengan pelet komersial.

\section{DAFTAR RUJUKAN}

Chan, W., J. Brown, S. M. Lee \& Buss, D. H. (1995). Meat and Poultry. The Royal Society of Chemistry, London.

Cheeke, P. R. (1987). Rabbit Feeding and Nutrition. Academic Press, INC. Florida.

Febriana, A. (2005). Pengaruh Penggantian Bungkil Kelapa Dengan Ampas Tahu Fermentasi Dalam Ransum Terhadap Kecernaan Bahan Kering Dan Bahan Organik Kelinci Lokal Jantan.

Hendra, S. B. B. (2009). Perbedaan performans anak kelinci lokal periode pra-sapih yang induknya diberi pakan komplit mengandung bungkil inti sawit dan bungkil kelapa. Skripsi. Fakultas Peternakan. Institut Pertanian Bogor. Bogor.

Sarwono, B. (2001). Kelinci Potong dan Hias. Agromedia Pastaka. Jakarta.

Suci, D.M. \& L Khotijah. (2017). Panduan Beternak Kelinci. Penebar Swadaya. Jakarta. 
Tamba, S., M. Ramli, \& Hendrik. (2006). Analisis Kelayakan Budidaya Kelinci Dalam Ternak Di Desa Silalahi III Kecamatan Silahisabungan Kabupatem Dairi Provinsi Sumatra Utara. Skripsi. Universitas Riau. 